\title{
A combined approach using differential scanning calorimetry with polarized light thermomicroscopy in the investigation of ketoprofen and nicotinamide cocrystal
}

\author{
G.L. Perpétuo ${ }^{\mathrm{a}, \mathrm{b}, *}$, G.O. Chierice ${ }^{\mathrm{a}}$, L.T. Ferreira ${ }^{\mathrm{c}}$, T.F.C. Fraga-Silva ${ }^{\mathrm{c}}$, J. Venturini ${ }^{\mathrm{c}}$, \\ M.S.P. Arruda ${ }^{\mathrm{c}}$, G. Bannach ${ }^{\mathrm{c}}$, R.A.E. Castro $^{\mathrm{d}}$ \\ a Instituto de Química de São Carlos - IQSC/USP, C.P. 780, CEP 13560-970 São Carlos, SP, Brazil \\ ${ }^{\mathrm{b}}$ Faculdades Integradas de Bauru - FIB, CEP 17056-100 Bauru, SP, Brazil \\ ${ }^{c}$ UNESP - Univ Estadual Paulista, Faculdade de Ciências, São Paulo CEP 17033-260, Brazil \\ d CQC, Faculty of Pharmacy, University of Coimbra, 3000-548 Coimbra, Portugal
}

\section{A R T I C L E I N F O}

\section{Article history:}

Received 15 July 2016

Received in revised form 16 February 2017

Accepted 18 February 2017

Available online 22 February 2017

\section{Keywords:}

Ketoprofen

Cocrystal

Nicotinamide

Thermomicroscopy

\begin{abstract}
A B S T R A C T
A screening of ketoprofen cocrystal with nicotinamide as a coformer was performed using the Kofler contact method and mechanochemistry. The crystallization of KET (with cocrystal formation) can occur during the heating process. However, although it is thermodynamically favorable, it was found that the kinetic reactions were slow, since the KET crystallization took about 30 days. The compounds obtained were analysed by differential scanning calorimetry (DSC), polarized light thermomicroscopy (PLTM), Fourier transform infrared spectroscopy (FTIR), and X-ray powder diffraction (XRPD). Cocrystal formation between ketoprofen and nicotinamide has great interest because the nicotinamide has FDA/GRAS status. At the adopted conditions, the achievement of cocrystal between ketoprofen and nicotinamide was not possible by mechanochemical methods However, experiments conducted by the Kofler method confirmed that ketoprofen interacted, under determined conditions, with nicotinamide giving rise to a new cocrystal. Furthermore, biological tests revealed that the KET + NA (1:1) eutectic system obtained by grinding had a greater anti-inflammatory action when compared to pure ketoprofen.
\end{abstract}

(c) 2017 Elsevier B.V. All rights reserved.

\section{Introduction}

Even after the marketing stage, an active pharmaceutical ingredient (API) is still the subject of research aimed at improving its physical and chemical properties, especially its solubility in water, since it operates as a solvent in the main biological systems [1].

There are several ways to improve the physicochemical properties of an API, such as salt formation, polymorphic forms and solvates or hydrates [2]. Recently, cocrystal screening has become an important and innovative approach to improve the physicochemical properties of an API by using appropriate molecules as coformers [2,3].

Ketoprofen (KET) or (RS)-2-(3-Benzoylphenyl)propionic acid (see Fig. 1a) is a non-steroidal anti-inflammatory and pertains to Class II (low solubility, high permeability) of the biopharma-

\footnotetext{
* Corresponding author at: Faculdades Integradas de Bauru - FIB. CEP 17056-120 Bauru, SP, Brazil.

E-mail address: glaucoperpetuo@yahoo.com.br (G.L. Perpétuo).
}

ceutics classification system (BCS) [4,5]. which is derived from phenylpropionic acid and characterized pharmacologically by its anti-inflammatory, antipyretic and analgesic action. For those reasons it is widely used in the medical and veterinary fields. Its mechanism of action is through the inhibition of prostaglandin and the synthesis of leukotriene [6].

The formation of supramolecular heterosynthons (Fig. 1b) is highly favored [7]. Based on this information, molecules that presented the functional groups shown in Fig. 1b were tracked and the choice of nicotinamide (NA) (Fig. 1c) as coformer was based on the fact that the FDA regards this substance as safe [8].

Another essential factor considered for the choice of the coformers was the pKa difference ( $\Delta \mathrm{pKa}$ ) between the API and the other molecules. An acid-aromatic nitrogen hydrogen bond can be formed if the $\Delta \mathrm{pKa}$ is less than 3.75 [9]. KET and NA fully satisfy this condition, since their pKa values are 4.53 [10] and 3.35 [11], respectively.

Kofler has published about 250 papers which describe the contact method to determine the phase diagrams of the binary mixtures of organic compounds. This method can provide a qualitative 
a)<smiles>CC(=O)OCC(=O)C(C)c1cccc(C(=O)c2ccccc2)c1</smiles>

b)

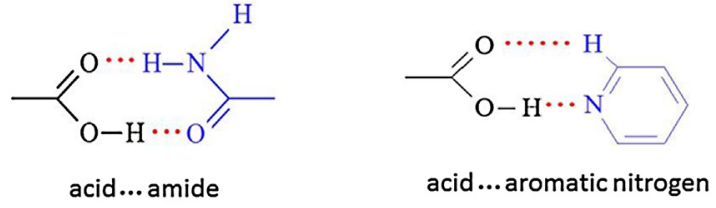

c)

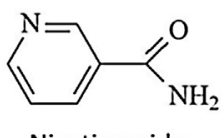

Nicotinamide

Fig. 1. (a) Ketoprofen, API. (b) Supramolecular heterosynthons. (c) Aromatic acid amide cocrystal formers.

and rapid indication about the formation of cocrystals and because of that it was used as an initial approach [12,13]. Subsequently, a grinding experiment was used to get possible cocrystals, that were analysed by DSC, FTIR and XRPD.

\section{Experimental procedures}

\subsection{Materials}

(RS)-Ketoprofen $98 \%$ and nicotinamide 99\% were purchased from Sigma-Aldrich Chem. Co. (St. Louis, MO, USA) and used without purification.

\subsection{Grinding}

A total mass of $50 \mathrm{mg}(\mathrm{KET}+\mathrm{NA})$ was grinded in a Retsch MM400 mill for $30 \mathrm{~min}$ at a frequency of $15 \mathrm{~Hz}$, in a $10 \mathrm{~mL}$ stainless steel jar with two stainless balls ( $7 \mathrm{~mm}$ diameter) inside.

\subsection{Polarized light thermal microscopy (PLTM)}

PLTM studies were performed in a Linkam hot stage system, model DSC600. For optical observation, it was used a Leica DMRB microscope and a Sony CCD-IRIS/RGB video camera. The images formed (200× magnification) were analysed through the Real Time Video Measurement System software by Linkam. The experiments of Kofler's contact method were accomplished according to Berry et al. [13].

\subsection{Differential scanning calorimetry (DSC)}

The DSC curves were obtained through the calorimeter Pyris1, PerkinElmer, with power compensation. A $30 \mu \mathrm{L}$ aluminum crucible hermetically sealed was used as a sample holder. A similar empty crucible was used as reference. All experiments were performed in nitrogen atmosphere with a flow rate of $20 \mathrm{~mL} \mathrm{~min}^{-1}$, with an approximate mass of sample equal to $2 \mathrm{mg}$. The enthalpy calibration was made with indium [14] and the temperature calibration was performed with the onset temperature of indium and standard benzoic acid $[14,15]$. A $5{ }^{\circ} \mathrm{C} \mathrm{min}^{-1}$ heating rate was adopted for all calibration processes.

\subsection{Fourier transform infrared spectroscopy (FTIR)}

Spectra of the solids were recorded at room temperature utilizing the attenuated total reflectance (ATR) technique and using a Bruker Vertex 70 spectrometer with a scanning range between 400 and $4000 \mathrm{~cm}^{-1}$ (resolution $4 \mathrm{~cm}^{-1}$ ) and a diamond crystal as support.

\subsection{X-ray powder diffraction (XRPD)}

X-ray powder diffractograms were obtained on a Siemens DMAX 2000 X-ray diffractometer using $\mathrm{Cu} \mathrm{K} \alpha$ radiation $(\lambda=1.5406 \AA)$ and settings of $20 \mathrm{kV}$ and $2 \mathrm{~mA}$. The samples were placed on a glass support and exposed to the radiation $\left(3^{\circ} \leq 2 \theta \leq 50^{\circ}\right)$.

\section{Biological activity}

\subsection{Isolation of peripheral blood mononuclear cells}

Blood from six healthy blood donors was collected with Vacutainer tubes containing heparin as an anticoagulant. The peripheral blood mononuclear cells (PBMC) were isolated by density gradient centrifugation on Histopaque ${ }^{\circledR}-1077$ (Sigma-Aldrich, St Louis, MO, USA). Cell viability, as determined by $0.2 \%$ trypan blue, was $>80 \%$ in all the experiments. The PBMC were counted using Turkís solution and the monocytes were counted using $0.02 \%$ neutral red. Both population cells were suspended to a concentration of $1 \times 10^{6}$ cells $/ \mathrm{ml}$ in complete medium.

\subsection{Cytotoxicity assay}

The cytotoxic activity of the KET + NA (1:1) was determined using the colorimetric microculture MTT assay (MTT=3-(4,5dimethyl-2-thiazolyl)-2,5-diphenyl-2H-tetrazolium bromide) [16]. The PBMCs were seeded in $100 \mu \mathrm{L}$ aliquots in RPMI-1640, supplemented with $20 \%$ heat-inactivated fetal bovine serum (SBF), into 96-well microculture plates. The eutectic compound KET + NA (1:1) was added in the PBMC culture and the plate was incubated for $96 \mathrm{~h}$ at $37^{\circ} \mathrm{C}$ in a humid atmosphere with $5 \% \mathrm{CO}_{2}$. Dimethylsulfoxide (DMSO) was subsequently added to dissolve the formazan crystals. Optical densities were measured using an ELISA microreader (EL800, BIO-TEK Instruments, INC) at a wavelength of $490 \mathrm{~nm}$. The quantity of viable cells was expressed by comparison between the treated cell cultures and the untreated control cultures. The cytotoxicity represented the concentrations that caused $50 \%$ inhibition.

\subsection{Monocyte cell culture}

Monocytes were seeded in $100 \mu \mathrm{L}$ aliquots in RPMI-1640, supplemented with $20 \% \mathrm{SBF}$, into 96 -well culture plates. To assess the influence of the KET + NA (1:1) on the inflammatory milieu, the monocytes were submitted to four treatments: 1) simultaneous stimulation with lipopolissacaride (LPS) $-10 \mu \mathrm{g} \mathrm{ml}^{-1}$ and KET + NA (1:1) (initial concentration); 2) LPS; 3 ) KET + NA (1:1); and 4) nonstimulated cell culture. Cells were incubated at $37^{\circ} \mathrm{C}$ and $5 \% \mathrm{CO}_{2}$. After $24 \mathrm{~h}$, the cell-free supernatants were collected to determine the cytokines and the cells were submitted to determination of the hydrogen peroxide release.

\subsection{Production of hydrogen peroxide $\left(\mathrm{H}_{2} \mathrm{O}_{2}\right)$}

A phenol red solution [dextrose 1\% (Sigma-Aldrich Chem. Co. (St. Louis, MO, USA), phenol red 1\% (Sigma-Aldrich Chem. Co. (St. Louis, MO, USA), horseradish peroxidase type II - 5 uni (Sigma-Aldrich 


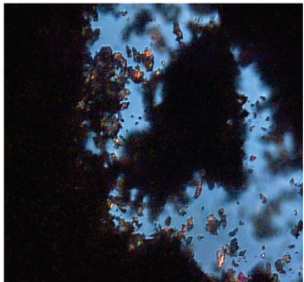

$25.0^{\circ} \mathrm{C}$

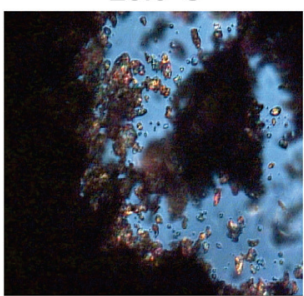

$94.2^{\circ} \mathrm{C}$

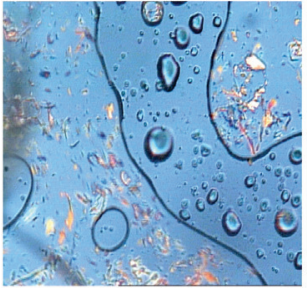

$95.6^{\circ} \mathrm{C}$

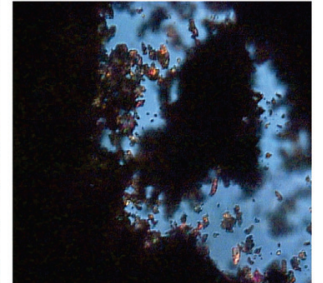

$50.0^{\circ} \mathrm{C}$

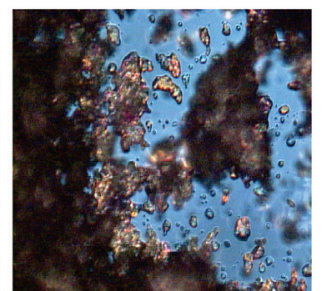

$94.5^{\circ} \mathrm{C}$

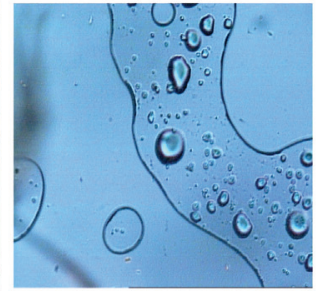

$96.4^{\circ} \mathrm{C}$

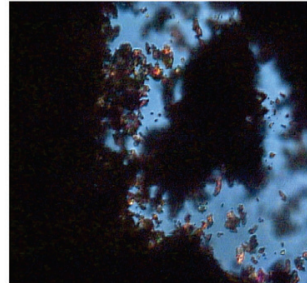

$75.0^{\circ} \mathrm{C}$

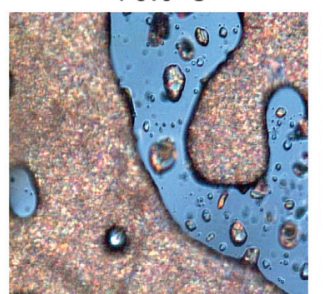

$94.9^{\circ} \mathrm{C}$

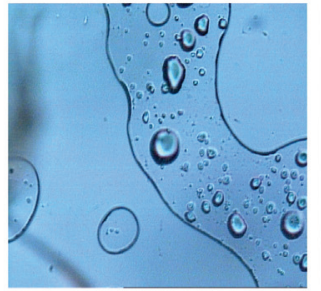

$96.8^{\circ} \mathrm{C}$

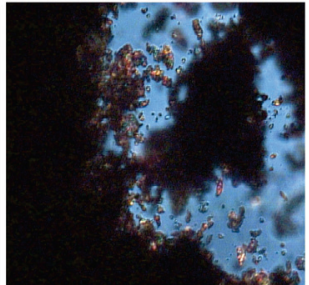

$93.9^{\circ} \mathrm{C}$

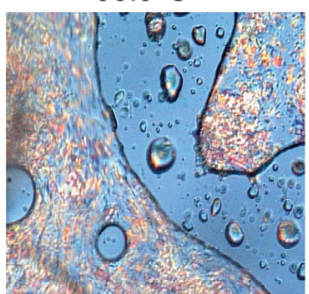

$95.2^{\circ} \mathrm{C}$

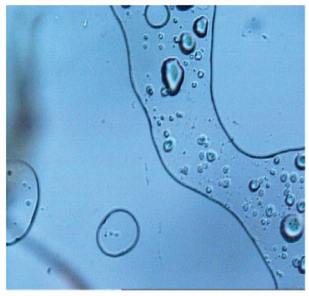

$100.0^{\circ} \mathrm{C}$

Fig. 2. KET first heating $\left(5^{\circ} \mathrm{C} \mathrm{min}^{-1}, \mathrm{~N}_{2}\right.$ atm., $200 \times$ magnification $)$.

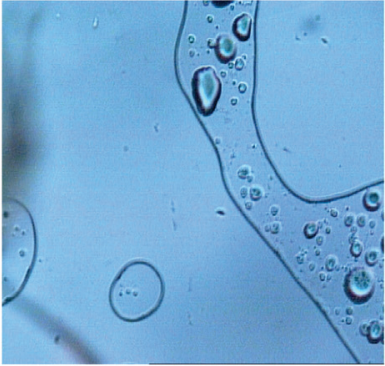

$75.0^{\circ} \mathrm{C}$

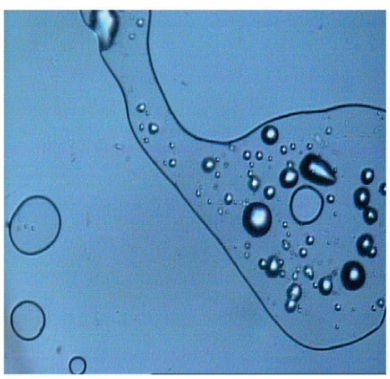

$-65.0^{\circ} \mathrm{C}$

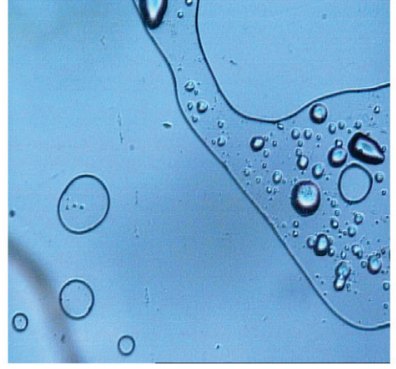

$25.0^{\circ} \mathrm{C}$

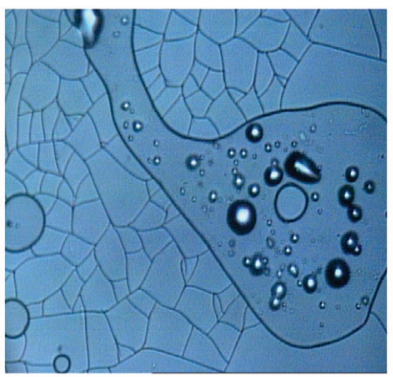

$-104.8^{\circ} \mathrm{C}$

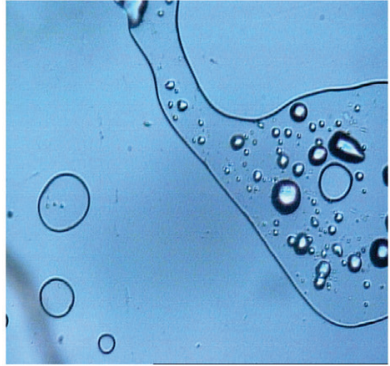

$0.0^{\circ} \mathrm{C}$

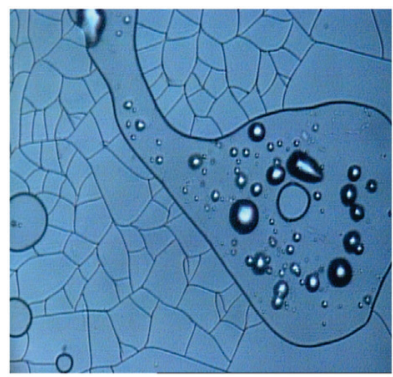

$-110.0^{\circ} \mathrm{C}$

Fig. 3. KET first cooling $\left(-5^{\circ} \mathrm{C} \mathrm{min}^{-1}, \mathrm{~N}_{2}\right.$ atm., $200 \times$ magnification $)$.

Chem. Co. (St. Louis, MO, USA)] was used for the monocytes incubation. Then, they were plated at $37^{\circ} \mathrm{C}$ in $\mathrm{CO} 25 \%$ for $1 \mathrm{~h}$ [17]. Concentration of $\mathrm{H}_{2} \mathrm{O}_{2}$ from each sample was determined by optical density (absorbance of $620 \mathrm{~nm}$ ) detection in a ELISA microreader (EL800, BIO-TEK Instruments, INC) based on the standard curves.

\subsection{Cytokine analysis}

The levels of interleukin-8 (IL-8), interleukin 1 beta (IL-1 $\beta$ ), interleukin 6 (IL-6), interleukin 10 (IL-10), tumor necrosis factor alpha (TNF- $\alpha$ ) and interleukin 12 (IL-12) p70 were determined by FACS (fluorescence-activated cell sorting) using BD cytometric bead array (CBA) (BD Biosciences, CA, USA). 
Table 1

Thermodynamic values for the first heating of the KET +NA (1:1) system at pressure $p=0.1 \mathrm{MPa}^{\mathrm{a}}$.

\begin{tabular}{|c|c|c|c|}
\hline & $T_{\text {onset }} /{ }^{\circ} \mathrm{C}$ & $\Delta_{\text {fus }} \mathrm{H} / \mathrm{kJ} \mathrm{mol}^{-1}$ & Refs. \\
\hline \multirow[t]{3}{*}{ KET } & 94.54 & 27.4 & [20] \\
\hline & 94.5 & 31.6 & [21] This work \\
\hline & 94.2 & 30.5 & \\
\hline \multirow[t]{4}{*}{ NA } & $128.2 \pm 0.2$ & $23.2 \pm 0.4$ & {$[22]$} \\
\hline & 128.1 & $23.7 \pm 0.2$ & {$[23,24]$} \\
\hline & 130.1 & $23.9 \pm 0.5$ & This work \\
\hline & 128.0 & 24.6 & \\
\hline KET + NA (1:1) & 54.6 & 33.2 & This work \\
\hline
\end{tabular}

a Standard uncertainties $\mathrm{u}$ are $\mathrm{u}(T)=0.2^{\circ} \mathrm{C}, \mathrm{u}(\Delta H)=0.5 \mathrm{~kJ} \mathrm{~mol}^{-1}, \mathrm{u}(p)=1 \mathrm{kPa}$.

\subsection{Statistical analysis}

The comparison between two paired groups was performed by T-paired test. All statistical analyses were conducted using GraphPad Prism 5.0 (GraphPad Software. Inc., San Diego, California, USA) and $\mathrm{p}<0.05$ was set up for statistical significance [18].

\section{Results and discussion}

\subsection{Thermal behavior of ketoprofen}

Fig. 2 shows the thermal behavior of ketoprofen when subjected to heating by the PLTM technique. In this experiment, a sample of pure ketoprofen was heated from 25 to $100^{\circ} \mathrm{C}$ at a rate of $5^{\circ} \mathrm{C} \mathrm{min}-1$ under nitrogen atmosphere. It was possible to verify that its melting started at $94.2^{\circ} \mathrm{C}$. The occurrence of this thermal event can be observed by DSC through the endothermic peak shown at cycle 1 in Fig. 5. The second cycle in Fig. 5 shows that the KET was in the liquid state at $25^{\circ} \mathrm{C}$ and that slightly below $0{ }^{\circ} \mathrm{C}$ it suffered a glass transition, by which it passed to the glassy state. In a second step, followed by PLTM, Fig. 3, the sample was cooled from 100 to $-110^{\circ} \mathrm{C}$ at a rate of $-5^{\circ} \mathrm{C} \mathrm{min}^{-1}$ in nitrogen atmosphere. It was not possible to make a clear distinction between liquid and glass states because, since the refractive index of a glass and a liquid are very close together, the images in Fig. 3 are identical for these two physical states. Indeed, in this Figure, it can be seen that at $-104.8^{\circ} \mathrm{C}$ the appearance of cracks occurred, proving that the KET was in a glassy state. DSC curves presented in Fig. 5 , cycle 2 , show around $0{ }^{\circ} \mathrm{C}$ a glass transition (liquid to glass state). On the following DSC curve, cycle 3 , it is observable a glass transition (glass to liquid) at $0{ }^{\circ} \mathrm{C}$. It is evident in PLTM images of Fig. 4 that the cracks of the glassy state disappear in the temperature interval from $-1.0^{\circ} \mathrm{C}$ until $4.1{ }^{\circ} \mathrm{C}()$.

Thus, the analysis of the thermal behavior of KET allowed us to make the following observations. Below $0^{\circ} \mathrm{C}$, the KET was in a glassy state (it cracked at $-104.8^{\circ} \mathrm{C}$ ). As the temperature increased, it absorbed thermal energy and passed to the liquid state at $0^{\circ} \mathrm{C}$. From that point, with increasing temperature, its thermal behavior followed the liquid line and it may have eventually gone down through the solid line (occurrence of crystallization with subsequent melting) or remained in the liquid state up to the melting temperature of the solid. These observations are illustrated in Fig. 6.

\subsection{Cocrystal screening using the Kofler contact method}

This experiment was performed according to Berry et al. [13]. For this, the NA was merged and allowed to solidify at room temperature. Then, the KET was melted so that, in the liquid phase, it was allowed to come into contact with the solidified NA. The system was kept in a desiccator at room temperature for about 30 days, sufficient time for the crystallization of the KET. After this period, the thermal behavior of the system was analysed by PLTM experiments.

Fig. 7 shows the images obtained during the heating of the KET from 25 to $140{ }^{\circ} \mathrm{C}$ at a rate of $2{ }^{\circ} \mathrm{C} \mathrm{min}^{-1}$ in a nitrogen atmosphere.
It is possible to see that the KET started melting at $80^{\circ} \mathrm{C}$. At around $120^{\circ} \mathrm{C}$ the beginning of the melting of the NA should have been observed. However, instead of that, what was observed was the formation of a cocrystal of KET and NA from $120^{\circ} \mathrm{C}$ onwards; this cocrystal began to melt from $140^{\circ} \mathrm{C}$ (Fig. 8). The sample was left to cool and in a second heating, this time up to $160^{\circ} \mathrm{C}$, it was observed that the melting of the co-crystal starts at about $145^{\circ} \mathrm{C}$ according to Figs. 8 and 9. Part of that sample was scraped off to a DSC capsule and the results showed that it had a completely cyclical thermal behavior, as shown in Fig. 9. Furthermore, after crystallization, FTIR experiments were performed and the spectrum is shown in Fig. 10 and compared to eutectic compound. These clearly point out the difference between the compounds. Among these spectra we would highlight the differences between the asymmetric stretches of the $\mathrm{NH}_{2}$ group of the NA, which arose at $3358 \mathrm{~cm}^{-1}$ in the KET + NA (1:1) compound and at $3230 \mathrm{~cm}^{-1}$ in the cocrystal, indicating that the amide group was involved in a stronger hydrogen bond in the cocrystal than that in the crystalline nicotinamide network. This stronger hydrogen bond stabilizes the cocrystal compared to the corresponding eutectic mixture [19].

\subsection{Sample prepared by mechanochemistry}

Cocrystal synthesis was tried by solid-state grinding. The solid mixture (1:1) obtained was analysed by DSC, XRPD and FTIR. The thermal behavior of this system is depicted in Fig. 11, and the respective thermodynamic values are shown in Table 1.

Fig. 11 shows that the NA melting occurred at $33.8^{\circ} \mathrm{C}\left(T_{\text {onset }}\right)$ above the melting temperature of the KET, whose values are shown in Table 1. The DSC curves of the KET + NA (1:1) mixture showed a peak with a lower melting temperature than the KET and NA, suggesting a formation of a cocrystal or a eutectic compound. One way to prove whether we were in the presence of a cocrystal or eutectic compound was by constructing a phase diagram. Thus, the milling was carried out in varying proportions to provide its construction. The samples were heated at a low heating rate $\left(5^{\circ} \mathrm{C} \mathrm{min}^{-1}\right)$, which was closer to the equilibrium. Fig. 12 shows the DSC curves obtained for each ratio. From the data of these curves, the phase diagram for a binary system comprising KET compounds and NA was constructed. Fig. 13 shows a typical diagram for the formation of an eutectic compound with a similar composition to that predicted by the Schroder-van Laar equation [25]. The phase diagram presented corresponds to a metastable phase diagram, since the cocristal is not presented [19] (see Appendix A for supplementary data). The theoretical eutectic composition was $0.64 \mathrm{~mol} \mathrm{KET}$, and composition determined experimentally was 0.61 mol KET. Thus, we can clearly verify that is not possible to obtain a cocrystal between KET and NA by grinding. Finally, the FTIR and XRPD experiments showed that the mixture (1:1) was not a cocrystal. Fig. 14a-c shows the XRPD patterns of pure compounds KET and NA and mixture KET + NA (1:1) obtained by milling, respectively. By analyzing these diffractograms, it can be seen by the dashed lines, that the XRPD pattern of the mixture KET + NA (1:1) is the sum of the other two 


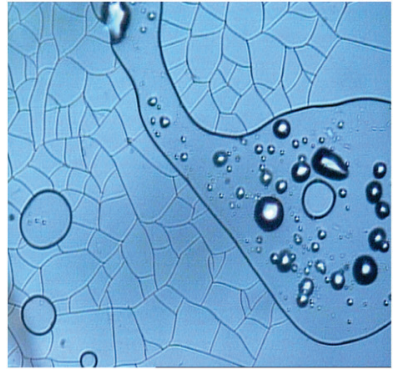

$-50.0^{\circ} \mathrm{C}$

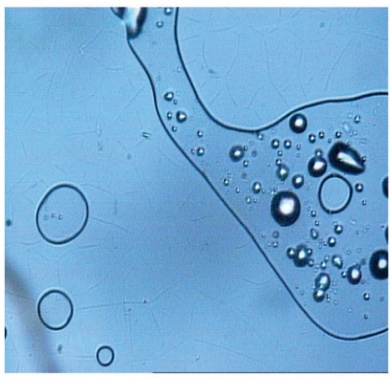

$4.1^{\circ} \mathrm{C}$

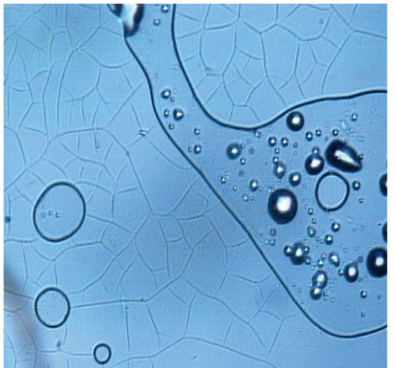

$-1.0^{\circ} \mathrm{C}$

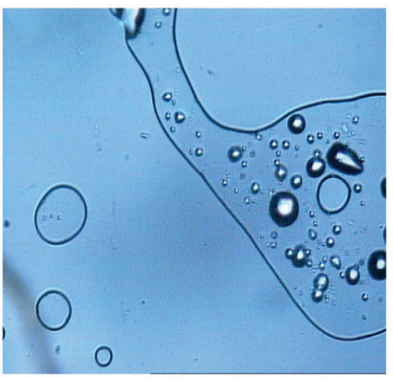

$5.8^{\circ} \mathrm{C}$

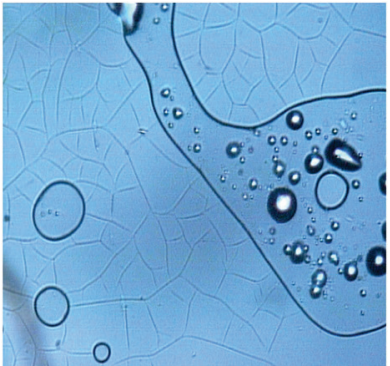

$0.0^{\circ} \mathrm{C}$

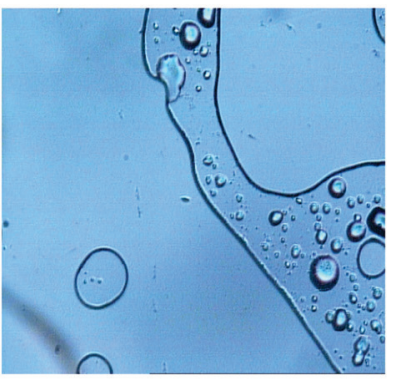

$25.0^{\circ} \mathrm{C}$

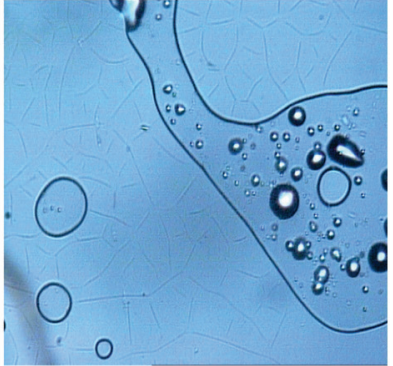

$3.2^{\circ} \mathrm{C}$

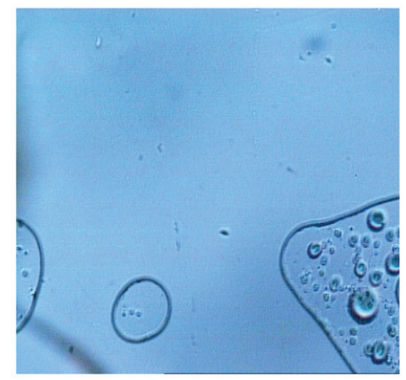

$75.0^{\circ} \mathrm{C}$

Fig. 4. KET second heating $\left(5^{\circ} \mathrm{C} \mathrm{min}^{-1}, \mathrm{~N}_{2}\right.$ atm., $200 \times$ magnification $)$.

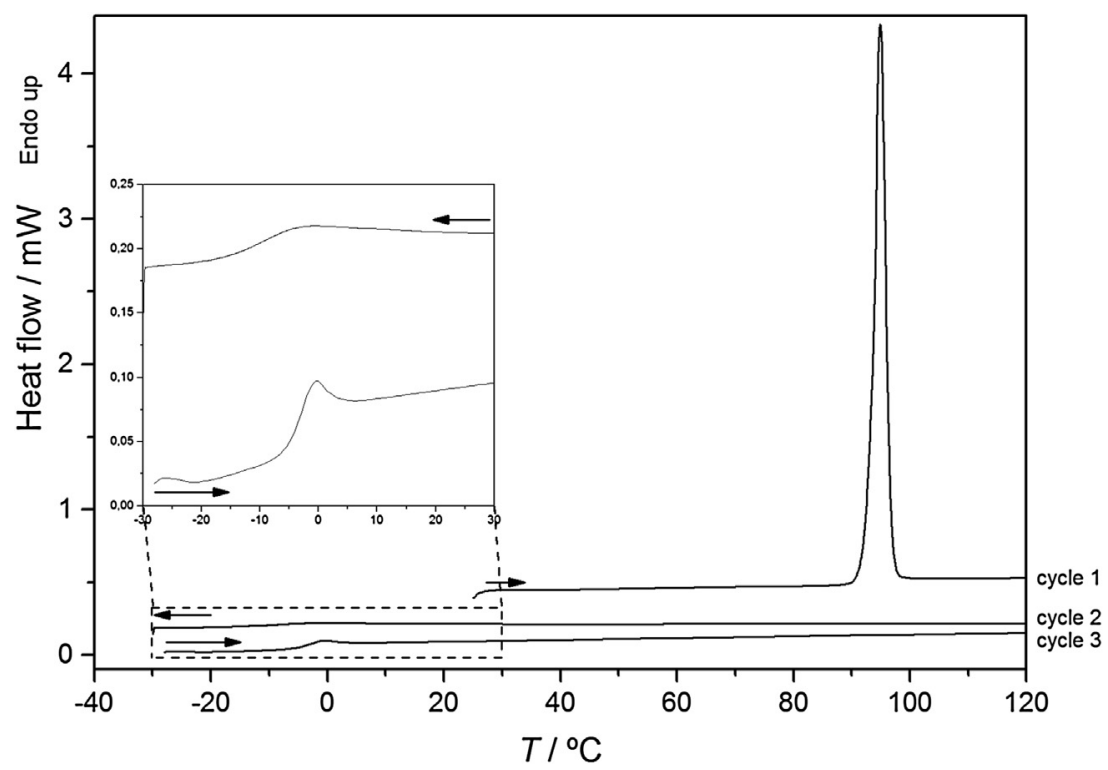

Fig. 5. Cyclic DSC of KET (2.5000 mg, $5^{\circ} \mathrm{C} \mathrm{min}^{-1}$ (heating and cooling), $\mathrm{N}_{2}$ atm., sealed aluminum crucible).

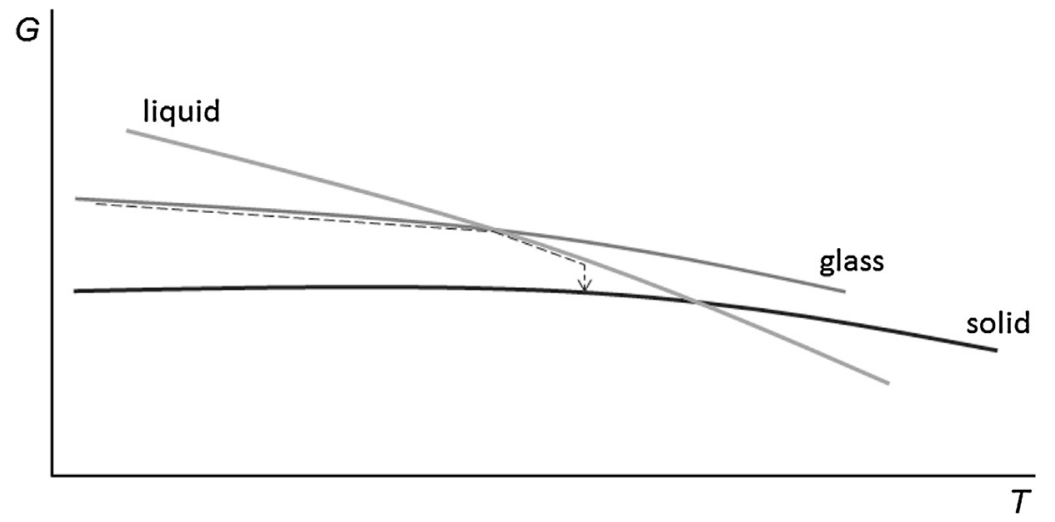

Fig. 6. Hypothetical phase diagram of KET. 


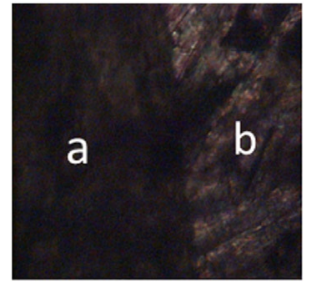

$25^{\circ} \mathrm{C}$

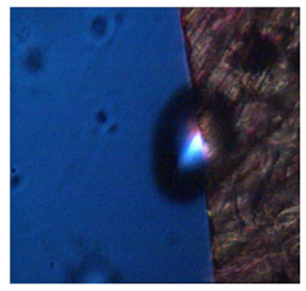

$90^{\circ} \mathrm{C}$

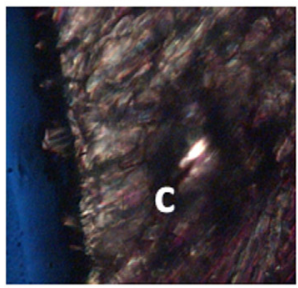

$125^{\circ} \mathrm{C}$

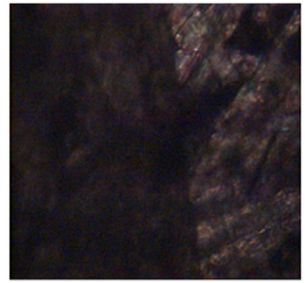

$50^{\circ} \mathrm{C}$

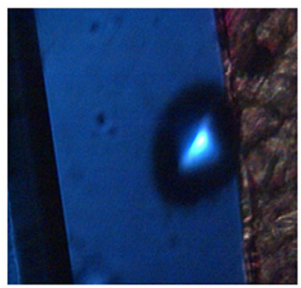

$105^{\circ} \mathrm{C}$

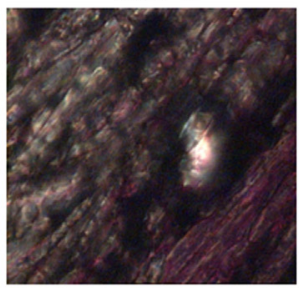

$129^{\circ} \mathrm{C}$

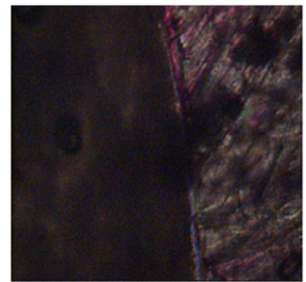

$80^{\circ} \mathrm{C}$

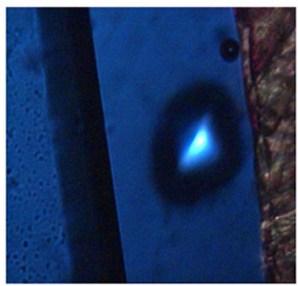

$110^{\circ} \mathrm{C}$

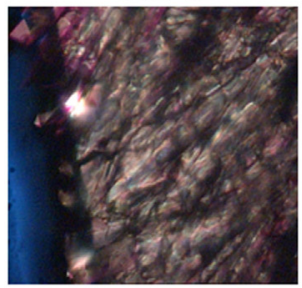

$130^{\circ} \mathrm{C}$

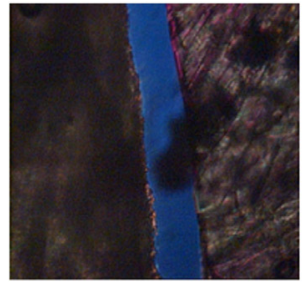

$85^{\circ} \mathrm{C}$

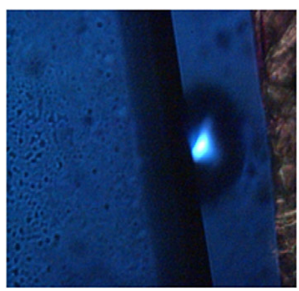

$115^{\circ} \mathrm{C}$

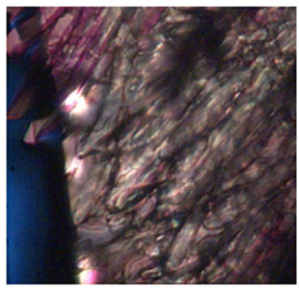

$135^{\circ} \mathrm{C}$

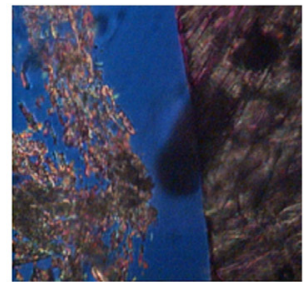

$88^{\circ} \mathrm{C}$

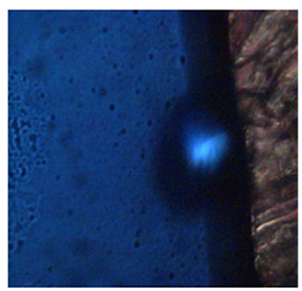

$120^{\circ} \mathrm{C}$

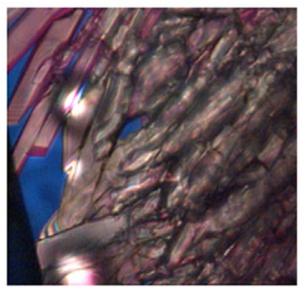

$140{ }^{\circ} \mathrm{C}$

Fig. 7. Heating of KET $+\mathrm{NA}$ system $\left(2^{\circ} \mathrm{Cmin}^{-1}, \mathrm{~N}_{2}\right.$ atm., $200 \times$ magnification $) \cdot \mathrm{a}=\mathrm{KET} ; \mathrm{b}=\mathrm{NA} ; \mathrm{c}=$ cocrystal formed

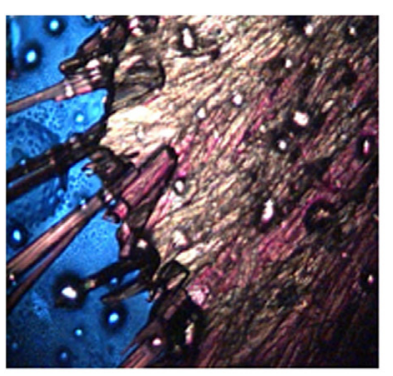

$50{ }^{\circ} \mathrm{C}$

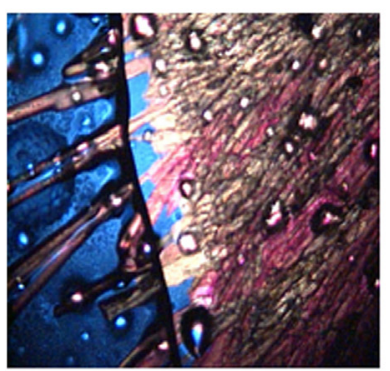

$135^{\circ} \mathrm{C}$

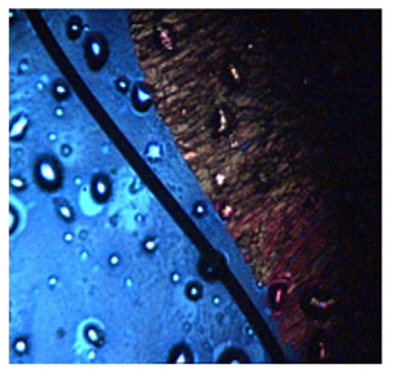

$150{ }^{\circ} \mathrm{C}$

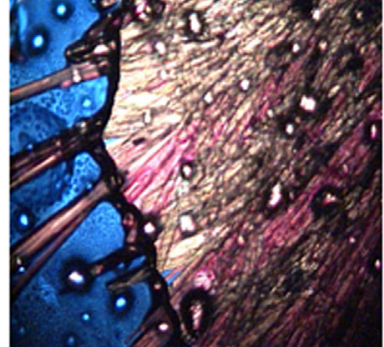

$100^{\circ} \mathrm{C}$

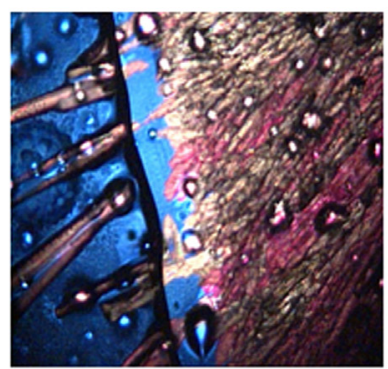

$140^{\circ} \mathrm{C}$

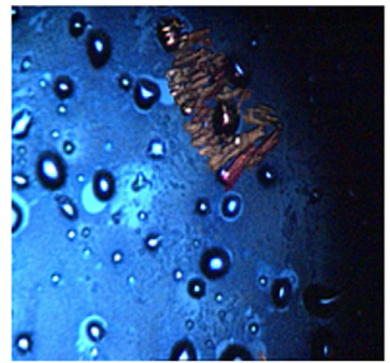

$152^{\circ} \mathrm{C}$

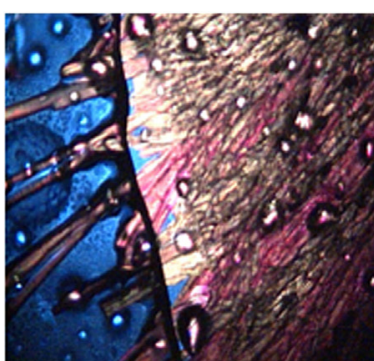

$130^{\circ} \mathrm{C}$

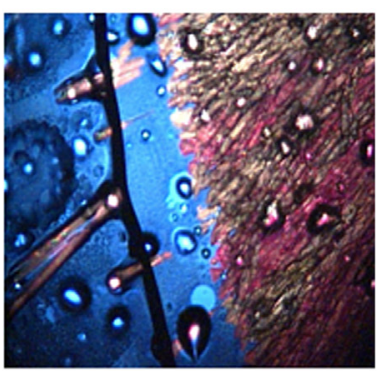

$145^{\circ} \mathrm{C}$

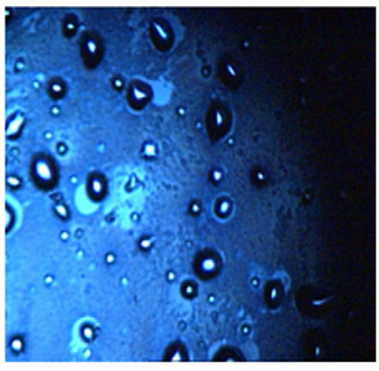

$153^{\circ} \mathrm{C}$

Fig. 8. Heating of the cocrystal formed $\left(5^{\circ} \mathrm{C} \mathrm{min}^{-1}, \mathrm{~N}_{2}\right.$ atm., $50 \times$ magnification $)$. 


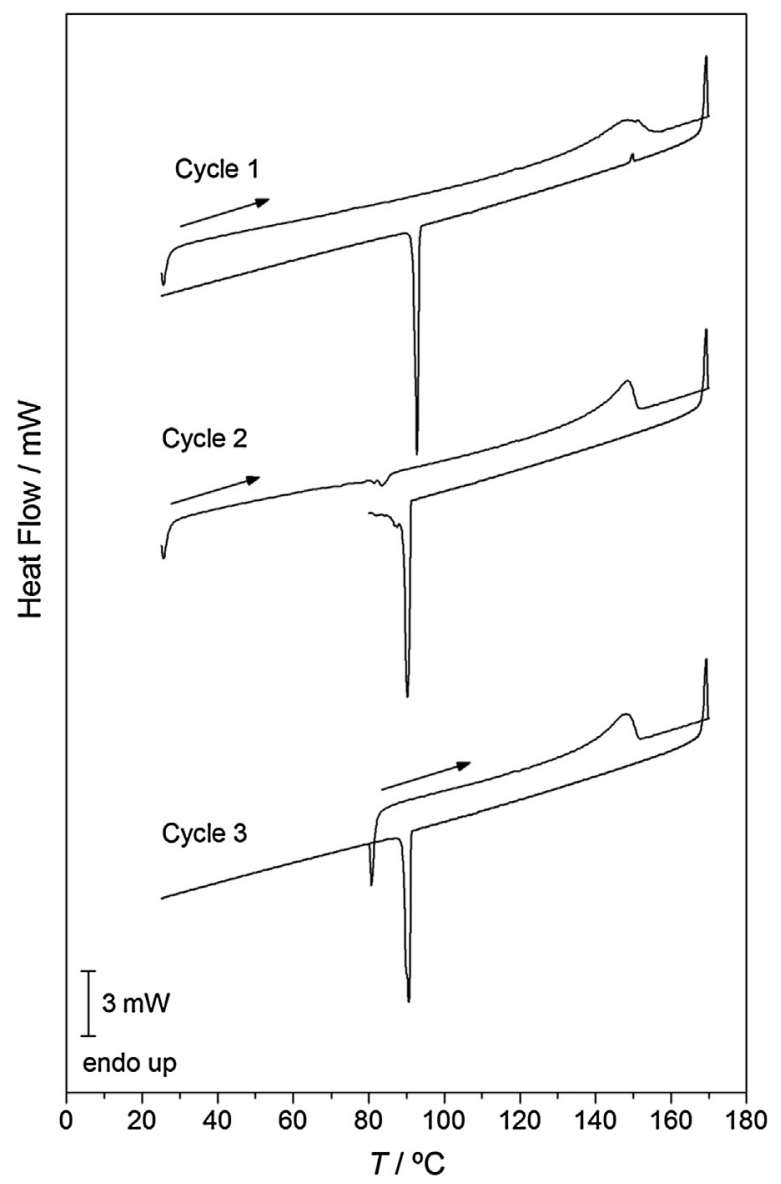

Fig. 9. Cyclic DSC of the KET:NA cocrystal.

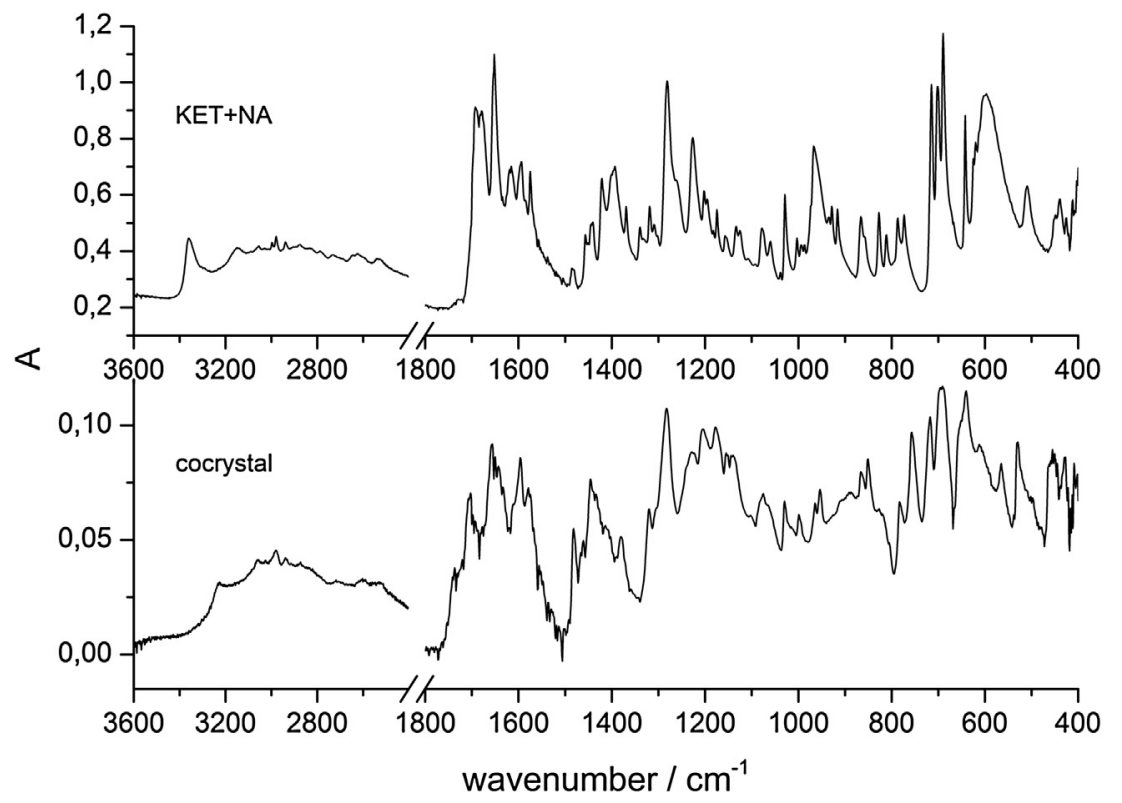

Fig. 10. FTIR of the eutectic KET + NA and cocrystal.

diffractograms, indicating no cocrystal formation. Fig. 15 also shows that the sum of pure KET and NA spectra were practically the same as the KET + NA mixture, proving that there was no interaction between KET and the NA to form a cocrystal.
We believe that this is due to the fact that the reaction kinetics were very slow, since the Kofler experiments proved that it is thermodynamically possible to obtain a cocrystal between these two compounds. 


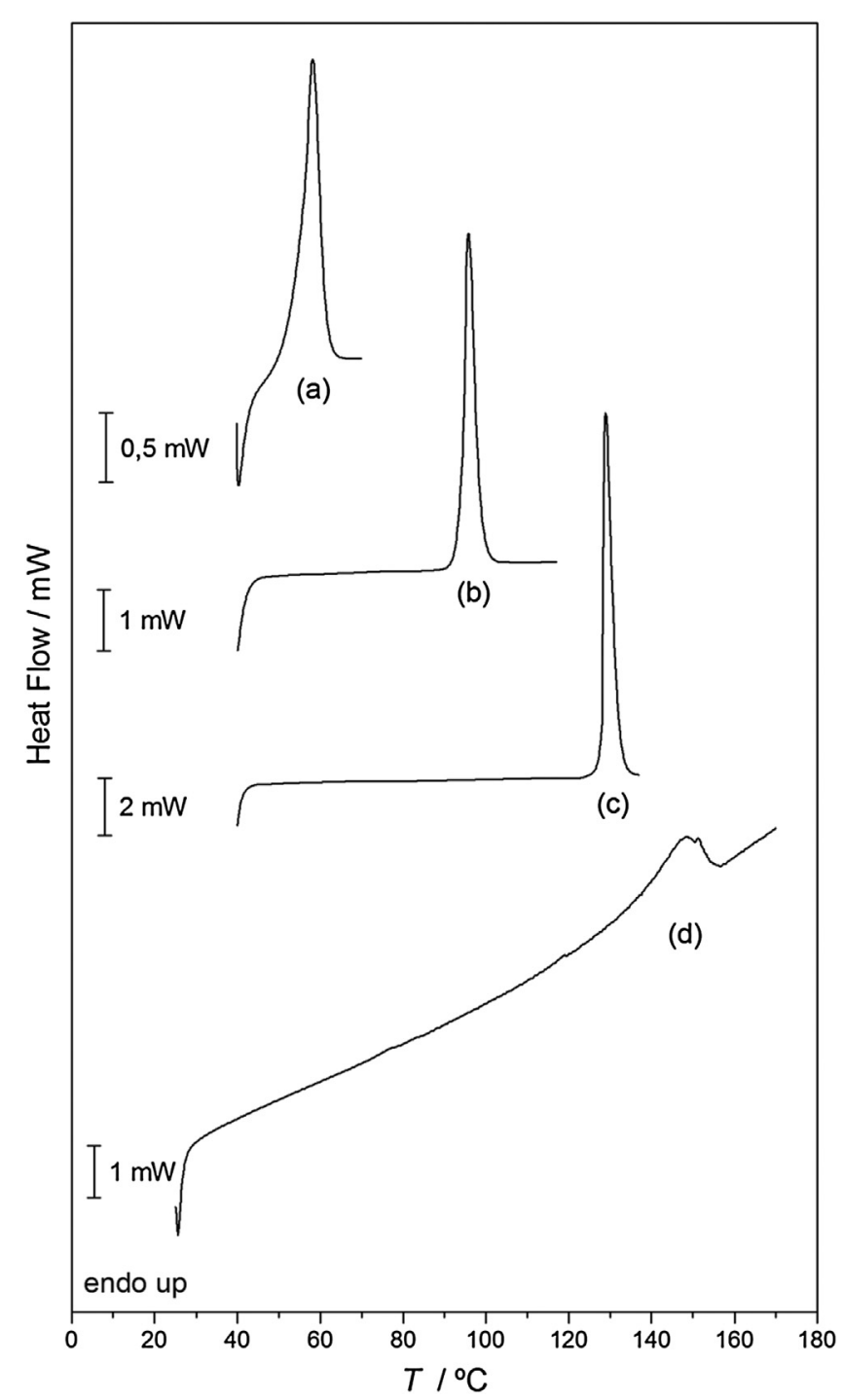

Fig. 11. DSC curves of the (a) KET + NA(1:1); (b) KET; (c) NA and (d) cocrystal ( $2 \mathrm{mg}, \mathrm{N}_{2}$ atm., heating rate of $5^{\circ} \mathrm{C} \mathrm{min}^{-1}$ ).

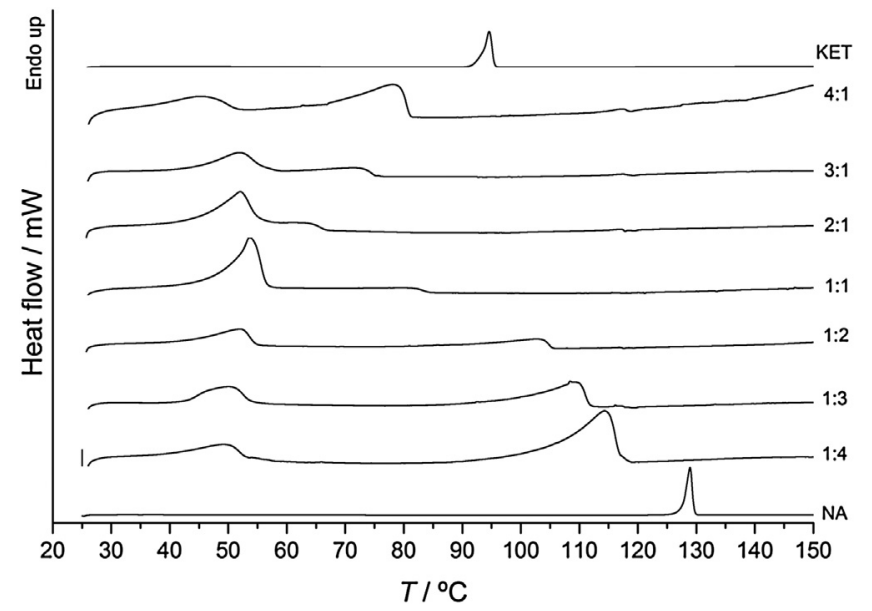

Fig. 12. DSC curves of the pure components KET, NA, and their proportions ( $2 \mathrm{mg}, \mathrm{N}_{2}$ atm., heating rate of $5^{\circ} \mathrm{C} \mathrm{min}-1$ ).

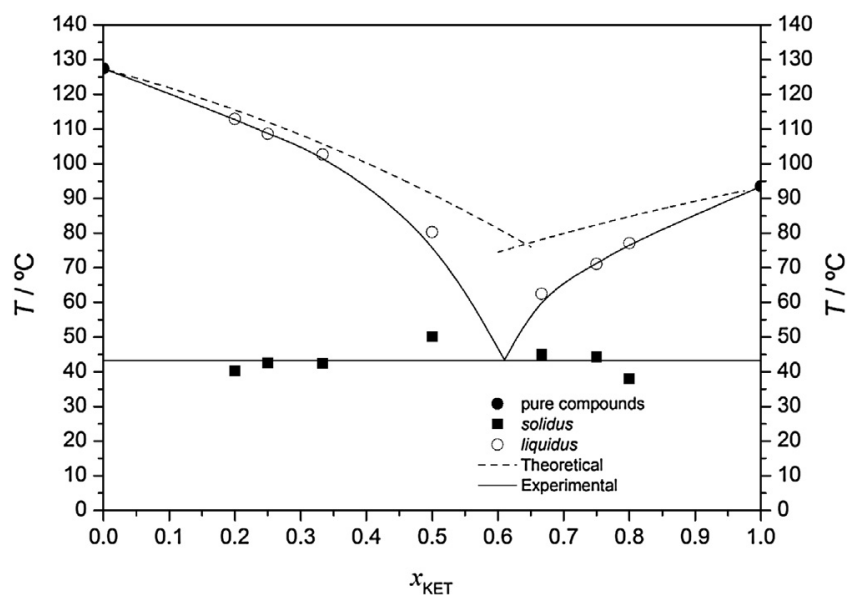

Fig. 13. Phase diagram for the KET + NA system.

\subsection{Biological assays}

The results demonstrated that KET + NA (1:1) did not alter cell viability in the initial concentration. At lower concentrations,

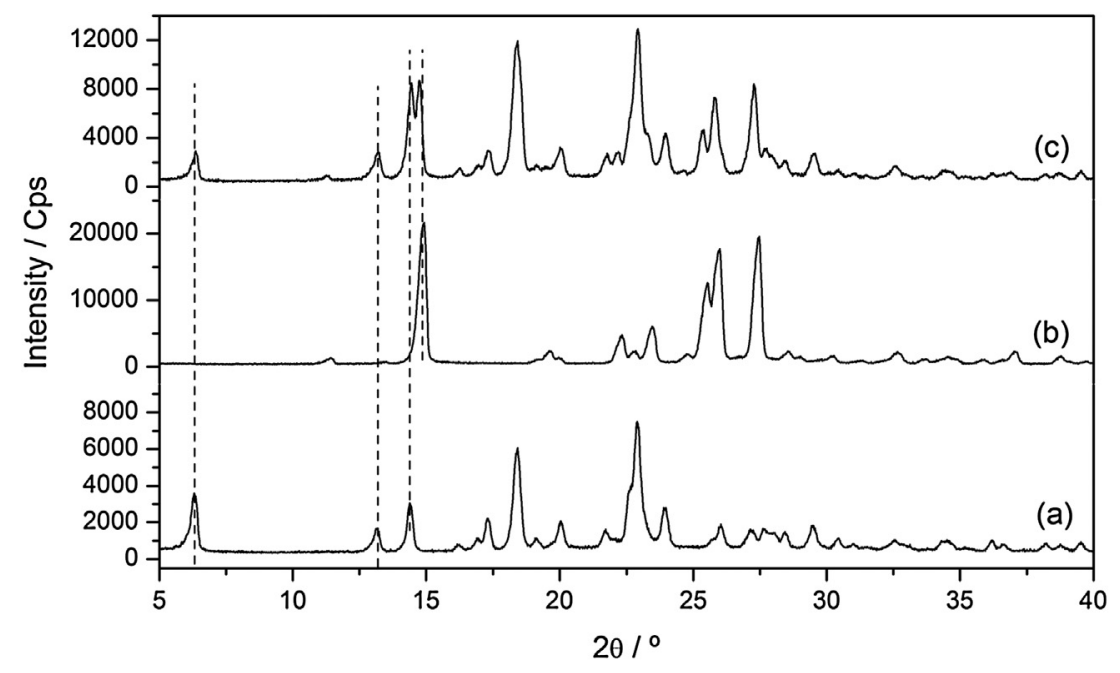

Fig. 14. X-ray diffractograms of (a) KET; (b) NA and (c) KET + NA (1:1). 
Table 2

Thermodynamic values for the first heating of the KET + NA (1:1) system. Pressure $p=0.1 \mathrm{MPa}^{\mathrm{a}}$.

\begin{tabular}{llll}
\hline & $T_{\text {onset }} /{ }^{\circ} \mathrm{C}$ & $T_{\text {peak }} /{ }^{\circ} \mathrm{C}$ & $\Delta_{\text {fus }} \mathrm{H} / \mathrm{kJ} \mathrm{mol}^{-1}$ \\
\hline KET & $94.2 \pm 0.1$ & $95.73 \pm 0.1$ & $30.5 \pm 0.2$ \\
NA & $128.0 \pm 0.1$ & $128.83 \pm 0.1$ & $24.6 \pm 0.2$ \\
KET + NA $(1: 1)$ & $54.6 \pm 0.2$ & $58.08 \pm 0.2$ & $33.2 \pm 0.2$ \\
\hline
\end{tabular}

a Standard uncertainties $\mathrm{u}$ are $\mathrm{u}, \mathrm{u}(p)=1 \mathrm{kPa}$.

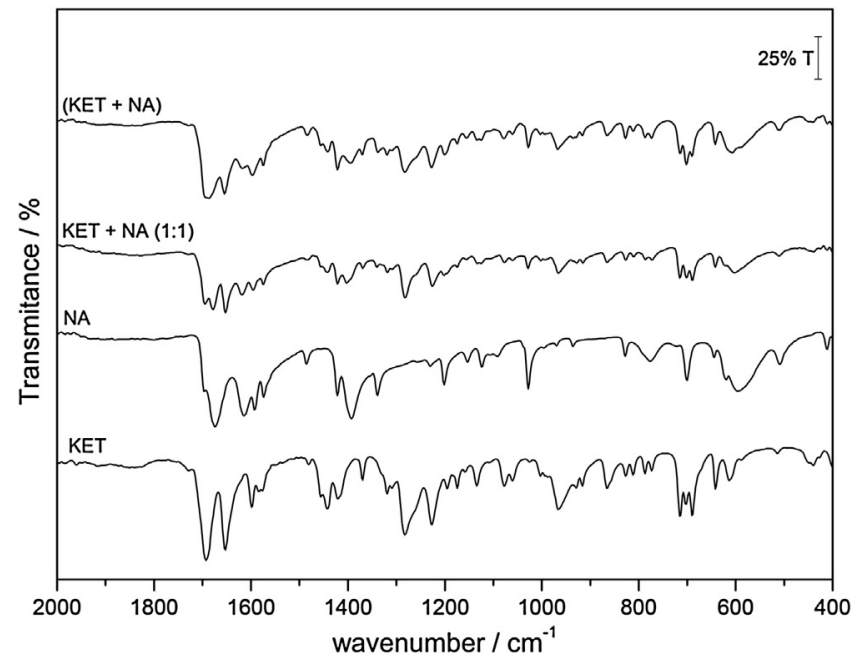

Fig. 15. FTIR spectra of KET + NA (1:1), KET and pure NA, as well as the sum of the spectra $($ KET + NA) of the pure compounds.

KET + NA (1:1) increased cell viability in comparison to KET (Fig. 16).

LPS-stimulated monocytes induced higher levels of tumor necrosis factor alpha (TNF- $\alpha$ ) and interleukin (IL)-1 $\beta$ and IL-10 (data not show). To assess the anti-inflammatory activity, LPSstimulated monocytes were cultured with KET or KET + NA (1:1); the results are summarized in Table 2 . The KET + NA (1:1) increased the production of hydrogen peroxide $\left(\mathrm{H}_{2} \mathrm{O}_{2}\right)$ in comparison to ketoprofen. However, the KET + NA (1:1) decreased TNF- $\alpha$ and IL-10 levels. The production of other cytokines, IL-1 $\beta$, IL-6 and IL-8, was similar between the KET and KET + NA (1:1) cultures. No IL-12p70 levels were detected in any sample.

Our results showed that the eutectic compound (KET + NA $(1: 1))$ altered the immunologic parameters of ketoprofen without cytotoxicity activity. This compound stimulated oxidative burst capacity and decreased inflammatory markers.

Reactive oxygen species such as $\mathrm{H}_{2} \mathrm{O}_{2}$, produced by phagocytes, are essential in a response to intracellular microorganisms, including Leishmania spp., Histoplasma capsulatum and Pneumocystis jiroveci [26-28]. Thus, KET + NA (1:1) showed the immunologic capacity to enhance the elimination of intracellular pathogens. Accordingly, patients with these types of infectious diseases, and which are in progression, demonstrate intense inflammatory processes, which are characterized by high serum levels of acute phase proteins and TNF- $\alpha[29,30]$. This inflammatory environment can cause deleterious effects, for example, cachexia [31]. The fact that KET + NA (1:1) decreases TNF- $\alpha$ production, suggests a potential to substitute thalidomide, which is an anti-TNF- $\alpha$ drug used as an anti-inflammatory that shows teratogenic effects [32].

$\mathrm{KET}+\mathrm{NA}(1: 1)$ increase $\mathrm{H}_{2} \mathrm{O}_{2}$ and simultaneously reduces TNF$\alpha$ production. Therefore, this compound represents a promising option for studies aimed at the immunotherapeutic treatment of patients infected by intracellular parasites and exhibiting intense pro-inflammatory activity.

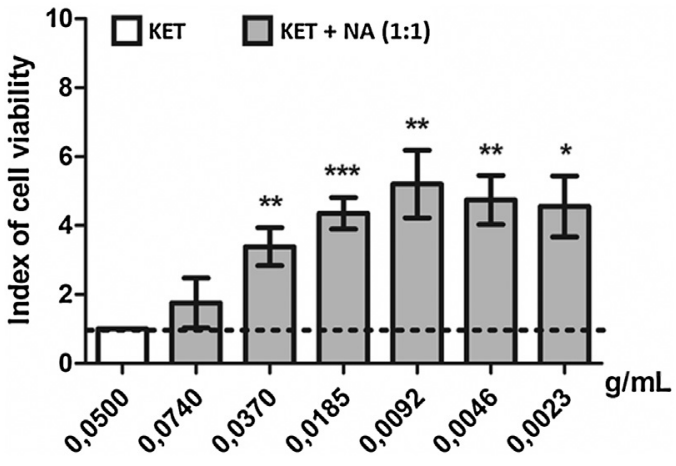

Fig. 16. Index of cell viability. Human PBMCs were stimulated with KET or KET + NA (1:1) in different concentrations and evaluated after $96 \mathrm{~h}$ by MTT assay. The index was expressed test-culture: control-culture ratio. The results are expressed as mean \pm SD. Paired $t$ test, ${ }^{*} \mathrm{p}<0.05,{ }^{* *} \mathrm{p}<0.01$ and ${ }^{* * *} \mathrm{p}<0.001$ in comparison to KET.

\section{Conclusions}

The screening process, which was based on the Kofler contact method, DSC and FTIR, indicated the discovery of a new cocrystal formed between ketoprofen and nicotinamide. Due to the peculiar thermal behavior of ketoprofen, it was not possible to obtain cocrystals from solution as well as through mechanochemistry experiments. Conversely, biological tests revealed that the compound obtained by grinding had a greater anti-inflammatory action compared to pure ketoprofen. Although the phase diagrams, DSC and XPRD experiments indicated that it was not possible to obtain cocrystals between KET and NA, the Kofler contact method and FTIR spectra confirmed the possibility of the formation of cocrystal between these two compounds. The crystallization of KET (with cocrystal formation) can occur during the heating process. However, although it is thermodynamically favorable, it was found that the kinetic reactions were slow, since the KET crystallization took about 30 days.

\section{Ethics statement}

This study was approved by the Research Ethics Committee of the Faculdade de Ciências de Bauru,UNESP, (Certificate of Presentation for Ethical Consideration - CAAE \#20497414.0.0000.5398). Written informed consent to participate and to publish the data was obtained and signed by all the participants.

\section{Acknowledgements}

The authors would like to thank the FAPESP (Procs. 2012/214501 and 2013/09022-7) and CNPq foundations (Brazil) for their financial support.

\section{Appendix A. Supplementary data}

Supplementary data associated with this article can be found, in the online version, at http://dx.doi.org/10.1016/j.tca.2017.02.014.

\section{References}

[1] F.G. Ferreira, Fármacos: do desenvolvimento à retirada do mercado, Rev. Electron. Farm. 6 (2009) 14-24.

[2] N. Schultheiss, A. Newman, Pharmaceutical cocrystals and their physicochemical properties, Cryst. Growth Des. 9 (2009) 2950-2967.

[3] J. Chen, B. Sarma, J.M. Evans, A.S. Myerson, Pharmaceutical crystallization, Cryst. Growth Des. 11 (2011) 887-895.

[4] T. Takagi, C. Ramachandran, M. Bermejo, S. Yamashita, L.X. Yu, G.L. Amidon, A provisional biopharmaceutical classification of the top 200 oral drug products in the United States, Great Britain, Spain and Japan, Mol. Pharm. 3 (6) (2006) $631-643$. 
[5] V.E. Thiel-Demby, J.E. Humphreys, L.A. St. John Williams, H.M. Ellens, N. Shah, A.D. Ayrton, J.W. Polli, Biopharmaceutics classification system: validation and learnings of an in vitro permeability assay, Mol. Pharm. 6 (1) (2008) 11-18.

[6] S. Miles Ketoprofen, in: S.J. Enna, D.B. Bylund (Eds.), xPharm: The Comprehensive Pharmacology Reference, Elsevier, 2008, pp. 1-7.

[7] T.R. Shattock, K.K. Arora, P. Vishweshwar, M.J. Zaworotko, Hierarchy of supramolecular synthons: persistent carboxylic acid $\cdots$ pyridine hydrogen bonds in cocrystals that also contain a hydroxyl moiety, Cryst. Growth Des. 8 (2008) 4533-4545

[8] U.S. Food and Drug Administration, Database of Select Committee on GRASS Substances (SCOGS) Reviews, 2015 (Accessed 20 feb 2015) http://www. accessdata.fda.gov/scripts/fcn/fcnNavigation.cfm?rpt=scogsListing.

[9] S.L. Johnson, K.A. Rumon, Infrared spectra of solid 1:1 pyridine-benzoic acid complexes; the nature of the hydrogen bond as a function of the acid-base levels in the complex, J. Phys. Chem. 69 (1) (1965) 74-86.

[10] I.E. Shohin, J.I. Kulinich, G.V. Ramenskaya, B. Abrahamsson, S. Koop, P. Langguth, J.B. Dressman, Baiowaiver monographs for immediate-release solid oral dosage forms: ketoprofen, J. Pharm. Sci. 101 (10) (2012) 3593-3603.

[11] H.G. Brittain, Appendix A, Profile of Drug Substances, Excipients, and Related Methodology, 33, Elsevier, 2007, pp. 282.

[12] D.J. Berry, C.C. Seaton, W. Clegg, R.W. Harrington, S.J. Coles, P.N. Horton, N. Blagden, Applying hot-stage microscopy to co-crystal screening: a study of nicotinamide with seven active pharmaceutical ingredients, Cryst. Growth Des. 8 (5) (2008) 1697-1712.

[13] G.P. Stahly, A survey of cocrystals reported prior to 2000, Cryst. Growth Des. 9 (10) (2009) 4212-4229.

[14] I.W. Group, R. Sabbah, A. Xu-Wu, M.P. Leitão, M.V. Roux, L.A. Torres, Reference materials for calorimetry and differential thermal analysis, Thermochim. Acta 331 (2) (1999) 93-204.

[15] G. Dalla Gatta, M.J. Richardson, S.M. Serge, S. Stolen, Standards, calibration, and guidelines in microcalorimetry Part 2. Calibration standards for differential scanning calorimetry, Pure Appl. Chem. 78 (7) (2006) 1455-1476.

[16] T. Mosmann, Rapid colorimetric assay for cellular growth and survival: application to proliferation and cytotoxicity assays, J. Immunol. Methods 65 (1-2) (1983) 55-63.

[17] M. Russo, H.C. Teixeira, M.C. Marcondes, J.A. Barbuto, Superoxide-independent hydrogen peroxide release by activated macrophages, Braz. J. Med. Biol. Res. 22 (10) (1989) 1271-1273.

[18] J.H. Zar, Biostatistical Analysis, 5th edition, Pearson Prentice-Hall, Upper Saddle River New Jersey, 2010.

[19] Y. Corvis, P. Négrier, M. Lazerges, S. Massip, J.-M. Léger, P. Espeau, Lidocaine/L-menthol binary system: cocrystallization versus solid-state immiscibility, J. Phys. Chem. B 114 (2010) 5420-5426.
[20] Y.H. Lu, C.B. Ching, Physicochemical properties, binary and ternary phase diagrams of ketoprofen, Chirality 16 (2004) 48.

[21] N. Belkacem, M.A. Sheikh Salem, H.S. AlKhatib, Effect of ultrasound on the physico-chemical properties of poorly soluble drugs: antisolvent sonocrystallization of ketoprofen, Powder Technol. 285 (2015) 16-24.

[22] R.A.E. Castro, J.D.B. Ribeiro, T.M.R. Maria, M. Ramos Silva, C. Yuste-Vivas, J Canotilho, M.E.S. Eusébio, Naproxen cocrystals with pyridinecarboxamide isomers, Cryst. Growth Des. 11 (2011) 5396-5404.

[23] A.R.R.P. Almeida, J.A.S.A. Oliveira, M.J.S. Monte, Thermodynamic study of nicotinamide, $\mathrm{N}$-methylnicotinamide and $\mathrm{N}, \mathrm{N}$-dimethylnicotinamide: vapour pressures phase diagrams, and hydrogen bonds, J. Chem. Thermodyn. 82 (2015) 108-115.

[24] A.A. Zhabina, R.N. Nagrimanov, V.N. Emel'yanenko, B.N. Solomonov, S.P. Verevkin, Nicotinamides: evaluation of thermochemical experimental properties, J. Chem. Thermodyn. 103 (2016) 69-75.

[25] S. Basak, P. Dasgupta, B. Das, M.K. Das, R. Dabrowski, Determination of orientational order parameters of two tri-Component mixtures from optical birefringence and X-ray diffraction measurements, Acta Phys. Pol. A 120 (6) (2011) 1037-1042.

[26] J.H. Zarley, B.E. Britigan, M.E. Wilson, Hydrogen peroxide-mediated toxicity for Leishmania donovani chagasi promastigotes, Role of hydroxyl radical and protection by heat shock, J. Clin. Invest. 88 (5) (1991) 1511-1521.

[27] E. Brummer, N. Kurita, S. Yoshida, K. Nishimura, M. Miyaji, Killing of Histoplasma capsulatum by gamma-interferon-activated human monocyte-derived macrophages: evidence for a superoxide anion-dependent mechanism, J. Med Microbiol. 35 (1) (1991) 29-34.

[28] H. Koziel, X. Li, M.Y. Armstrong, F.F. Richards, R.M. Rose, Alveolar macrophages from human immunodeficiency virus-infected persons demonstrate impaired oxidative burst response to Pneumocystis carinii in vitro, Am. J. Respir. Cell Mol. Biol. 23 (4) (2000) 452-459.

[29] R.A. Goodwin Jr., J.L. Shapiro, G.H. Thurman, S.S. Thurman, R.M. Des Prez, Disseminated histoplasmosis: clinical and pathologic correlations, Medicine (Balt.) 59 (1) (1980) 1-33.

[30] F.J. Medrano, C. Rey, M. Leal, C. Ca avate, A. Rubio, A. Sánchez-Quijano, E. Lissen, Dynamics of serum cytokines in patients with visceral leishmaniasis and HIV-1 co-infection, Clin. Exp. Immunol. 114 (1998) 403-407.

[31] K.J. Tracey, A. Cerami, Tumor necrosis factor and regulation of metabolism in infection: role of systemic versus tissue levels, Exp. Biol. Med. 200 (2) (1992) 233-239.

[32] S. Majumder, S. Rama Chaitanya Sreedhara, S. Banerjee, S. Chatterjee, TNF $\alpha$ signaling beholds thalidomide saga: a review of mechanistic role of TNF- $\alpha$ signaling under thalidomide, Curr. Top. Med. Chem. 12 (13) (2012) 1456-1467. 